\title{
Corporate Reputation Management Decisions: Customer's Perspective
}

\author{
Karolina Petrokaite, Jurgita Stravinskiene
}

\author{
Kaunas University of Technology \\ K.Donelaicio st. 73, LT-44029, Kaunas, Lithuania \\ e-mail: karolina.petrokaite@yahoo.com,jurgita.stravinskiene@ktu.lt
}

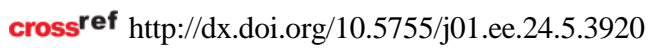

\begin{abstract}
When corporate reputation is analyzed from the perspective of relationship equity and communication, the analysis frequently appeals to expectations and experience of customers as the most important group of stakeholders. Yet in practice there are no methodologies of corporate reputation management of this kind that could be easily adapted and would capture the impact of reputation management decisions for sustainable customer confidence in the organization. Therefore, the research problem is structured as a question, i.e. what is the impact of corporate reputation on customer's confidence in the organization?

The proposed hypothetic model of corporate reputation management embeds customer-characteristic factors of corporate reputation perception, qualities that are inherent in the efficient management of integrated communication and reputation, and consequences of corporate reputation management in relationship to specific changes of customer behavior. The model illustrates the following assumption. The positive experience of a customer that was obtained by means of the perceived economic and social value during the development of relationship, conditions the basic outcome of positive corporate reputation, i.e. consumer advocacy which becomes evident through: increasing customer loyalty to the organization; public representation, i.e. declared confidence of the customers and their commitments in respect of the organization; increasing need for cooperation, i.e. the wish of customers to share information, participate in conflict solving and seek for mutually favorable possibilities of relationship with the organization.

The information, acquired during the empirical research, yields the conclusion that all customer perception-based reputation factors, i.e. quality of goods and services, emotional appeal, vision, leadership and social responsibility, have to be strengthened in communication practices.
\end{abstract}

Keywords: corporate reputation, corporate reputation management, stakeholder groups, consumer perspective, communication.

\section{Introduction}

In modern market the abilities of organizations to develop a value added unfold in a more subtle social context of corporate identity. Global practices indicate that such abstract notions like identity, image and reputation of an organization have become both significant tools to model customer behavior and elements of social status of the organization.

The notion of reputation and the concern with the image of the organization are not new ideas within the social context. Yet, the need to manage the reputation of the organization purposefully, systematically and judiciously is discussed more frequently. The rising need for transparency of organizational performance, increase of the impact of communication and dynamic business environment promote debate about new attitude towards the communication and relationship of the organization with important groups of stakeholders, i.e. reputation management, efficiency of which is usually described as financial and strategic benefit, provided by means of the reputation. The assumption mentioned above reveals the fact that expectations and experience of stakeholder groups become antecedents that are strategically important for decisions of reputation management.

(Covey \& Merrill, 2008) argues that confidence develops a speed, whereas the speed in contemporary markets determines competitive success. With the aim to develop confidence-based relationship with the groups of stakeholders and acquire a unique competitive advantage in the market, it is necessary to be able to evaluate factors of corporate reputation that determine the perception of stakeholder groups, corporate reputation-based expectations and organizational commitments, structured on the basis of the expectations. When the reputation of the organization is analyzed through relationship equity and communication, an appeal to the expectations and experience of customers as the most important group of stakeholders is usually made. However, no methodology which could be easily adapted for this type of corporate reputation management and which would capture the impact of reputation management decisions for sustainable customer confidence in the organization exists practically.

Therefore, the research problem is structured as a question, i.e. what is the impact of corporate reputation on customer's confidence in the organization?

The focus of the research dwells on corporate reputation management.

The article aims to develop a hypothetical model of corporate reputation management and test it empirically from a perspective of customers.

The research methods involve systemic and comparative analysis of academic literature and publications, correlation and regression data analysis, and a method of e-survey. 


\section{Connection of corporate reputation and stakeholder groups}

The rapid development of contemporary markets and constantly increasing scale of competition stimulate active discussions about the strategic value and relevancy of corporate reputation as a type of intangible asset of the organization. (Highhouse et al., 2009) claim that in the context of social maturity of organizations, reputation should be treated as unique resource that develops long-term based added value of the organization. Whereas (Shamma \& Hassan, 2009) believe the reputation to be the most important strategic resource that organizations achieve during a long term.

According to (Gotsi \& Wilson, 2001; Shamma \& Hassan, 2009; Walker, 2010), corporate reputation should be considered as the outcome of the past activity of the organization that has impact on the present behavior of stakeholder groups towards the organization. Due to this reason and in the context of strategic management, corporate reputation becomes a phenomenon that entails a collective position of stakeholder groups to the organization. In addition to this, (Shamma \& Hassan, 2009) argue that the attitude, characteristic to the theory of strategic management, demonstrates corporate reputation to be dependent on the process of information change and many social factors that affect expectations of stakeholder groups.

The opinions of (Weigelt, 1988; Camerer, 1988; Fombrun, 1996; Weiss, 1999; Bennett, 2000; Kottasz, 2000; Fombrun \& van Riel, 2004) to corporate reputation reveal that corporate reputation is a set of attributes that reflect results of the past behavior of the organization, its ability to satisfy expectations and, on the basis of the expectations, to develop value for stakeholder groups (Chun, 2005). It has to be mentioned that in terms of social aspects corporate reputation is assigned to a category of collective decisions, i.e. public opinions about the organization that are usually based on the model of organizational behavior.

Puncheva (2008) emphasizes that corporate reputation becomes one of the most essential factors that determine decision-making results of stakeholder groups. This becomes a sufficiently valid assumption, which allows making a claim that commitments of the organization and emerging expectations of stakeholder groups respectively are the crucial motives for the development of corporate responsibility that affirm the relevancy of corporate reputation in processes of decision making and relationship development. Romenti (2010) considers the expectations of stakeholder groups to be the basic element in corporate reputation management.

Academic literature and publications about organizations conceptualize stakeholder groups as individuals or groups that:

- experience and/or evoke risk in relationship with the organization (Vivader-Cohen, 2007);

- could benefit or influenced in a negative way (Davies et al., 2003);

- could have impact on organizational aims and be affected during the process of achieving the aims (Freeman et al., 2007; Sontaite, 2011).
According to (Neville et al., 2005), stakeholders make up any group and/or separate individuals, who can directly affect or be affected by commitments and aims of the organization. The analysis of corporate reputation that is based on expectations of stakeholder groups, is directed towards the development of relationship that in the longterm perspective is defined as an important area of intellectual capital, i.e. relationship equity. The researchers mentioned above argue that the impact of stakeholder groups on the organization occurs through the main four groups of actions:

- formation of expectations that are directly linked to the performance of the organization;

- impact of experience effect on decision making;

- evaluation of results of organizational performance;

- behavioral changes that are based on results of the evaluation of organizational performance.

The organization depends on various groups of stakeholders which are not controlled directly, yet they are important as the factor that conditions changes, related with corporate reputation. As Freeman (2009) suggests, there are twelve groups of stakeholder that are important for organizations. They are owners, customers, employees, competitors, suppliers, political groups, governmental organizations, financial groups, activists, unions, trade associations, and proponents of consumer rights (Sontaite, 2011). Corporate reputation management integrates the previous experience of stakeholder groups and direct organization-related expectations. Such an attitude allows making a claim that the experience of stakeholder groups is a static element of reputation management, whereas emerging expectations become a dynamic variable, which is largely dependent on efforts of the organization and develops a continuous experience of stakeholder groups.

Helm (2007) believes that, in a broad sense, corporate reputation is composed of a complex of specific cases of corporate reputation perception, which are characteristic to separate groups of stakeholders:

- customer-specific perception;

- investor-specific perception;

- employee-specific perception;

- supplier-specific perception;

- particularity of common corporate reputation in the social context.

When discussing separate groups of stakeholders, a shifting complex of factors that structure the perception of corporate reputation becomes the main reason for the differentiated perception of corporate reputation (Helm, 2007). The reputation of a firm is developed on the basis of expectations of stakeholder groups by means of the main six factors of corporate reputation perception, i.e. emotional appeal, quality of goods and services, vision and leadership, results of financial activity, working conditions and social responsibility. The significance of the factors changes against each group of stakeholders (Table 1).

Despite the fact that corporate reputation is a result of the intangible collective perception, it should be noted that separate groups of stakeholders are oriented towards different perception factors of corporate reputation and their importance cannot be made absolute in a generic sense. 
Summary of factors for perceiving corporate reputation (CR)

\begin{tabular}{|c|c|c|}
\hline \multirow{2}{*}{ Stakeholder groups } & \multicolumn{2}{|c|}{ Complex of factors to perceive corporate reputation (CR) } \\
\hline & Primary factors to perceive $\mathbf{C R}$ & Secondary factors to perceive $\mathbf{C R}$ \\
\hline Customers & Quality of goods and services & $\begin{array}{l}\text { Vision and leadership; } \\
\text { Emotional appeal. }\end{array}$ \\
\hline Investors & Results of financial activity & $\begin{array}{l}\text { Vision and leadership; } \\
\text { Quality of goods and services; } \\
\text { Emotional appeal. }\end{array}$ \\
\hline Employees & Working conditions & $\begin{array}{l}\text { Social responsibility; } \\
\text { Results of financial activity; } \\
\text { Vision and leadership; } \\
\text { Quality of goods and services. }\end{array}$ \\
\hline Suppliers & Results of financial activity & Quality of goods and services. \\
\hline Society & Social responsibility & Emotional appeal. \\
\hline
\end{tabular}

Source: composed by the authors of the article, with reference to Helm (2007).

Despite the fact that corporate reputation is a result of the intangible collective perception, it should be noted that separate groups of stakeholders are oriented towards different perception factors of corporate reputation and their importance cannot be made absolute in a generic sense.

(Siano et al., 2007) suggest that direct consumer experience in relationship to goods/services of the organization becomes the most important variable of corporate reputation management. It has to be emphasized that direct experience of customers appeals not only to the quality of goods/services but also to a generalized evaluation of organizational performance in the face of other groups of stakeholders (Helm, 2007). Ethical and socially responsible behavior of the organization, which is implemented by means of concentrated and qualitatively measured initiatives, i.e. investments into an ecological production line and suitable resources, consumer education, following the principles of business ethics, form public opinions about organizational behavior, which affect changes of corporate image and reputation. In this case the development of relationship with customers and the parallel management of corporate reputation become underlying activities of the organization.

As (Siano et al., 2007) state, the right perception of stakeholder groups that is related with the organization and its historic nature, depends on the ability of the organization to communicate. Thus, the communication, maintained by the organization, builds confidence-based relationship with separate groups of stakeholders (Dickinson-Delaporte et al., 2010). The interaction of corporate reputation and relationship with stakeholder groups is based on two antecedents of the process for developing the equity of relationship. They are familiarity and active communication behavior (Sohn, 2010). The notion of familiarity entails the stability of relationship, maintained with the organization, and their significance for the groups of stakeholder. Whereas, the notion of active communication behavior is oriented towards the factors that stimulate it, i.e. recognition of organizational problems and restrictions, and the involvement of the organization and the community in the process of problem solving. It is possible to state that familiarity is a hypothetical antecedent that has impact on corporate reputation and relationship of the organization with stakeholder groups. Meanwhile communication behavior directly affects the process of relationship development, and, as a result of the process, corporate reputation. In this respect corporate reputation is recognized as the output of the process of relationship development, and the communication of organization as the core element of the process. In summary it is possible to claim that common corporate reputation is a construct that captures a collective perception about the organization, or might be treated as synthesis of opinions, expectations and attitudes of different stakeholder groups, marked by different characteristic. Therefore, separate evaluations of corporate reputation converge in-between and form a generalized perception of corporate reputation. Whereas the ability of the organization to shape this type of experience might be treated as a full-fledged competitive advantage. The direct experience of customers that appeals both to the quality of goods/services and the consolidated evaluation of organizational performance in the light of other groups of stakeholders, actualizes the development of the relationship with customers and the management of corporate reputation in parallel as the underlying activities of the organization.

\section{Hypothetical model for managing corporate reputation: customer's perspective}

The approach of (Siano et al., 2007; Greyser, 2009; Romenti, 2010; Doorley \& Garcia, 2011) suggests that management of corporate reputation and communication is an integrated process, thus the assumptions for developing the hypothetical model of corporate reputation management are the following ones:

- the main factors to perceive corporate reputation are emotional appeal, quality of goods and services, vision and leadership, results of financial activity, working conditions, and social responsibility (Helm, 2007);

- the endogenous factors of corporate reputation that describe active communication behavior of the organization are public relations, connections with the mass media, different forms of advertising, publicly accessed information about the organization, and communication on topics relevant for the society (Siano et al., 2007);

- the desirable and favorable reputation of the organization is acquired through all areas of the expression of corporate identity, i.e. the behavior, communication and symbolism of the organization. The interaction of corporate reputation and identity reveals the main five dimensions of corporate reputation, i.e. visibility, distinctiveness, authenticity, transparency and consistency (van den Bosch et al., 2005); 
- corporate reputation depends on confidence, that is formed among stakeholder groups, and respect to the organization (Siano et al., 2007; Berens \& van Riel, 2004).

Therefore, the following assumption is made, that corporate communication, which is marked by qualities of efficient and integrated process of communication and reputation management, allows achieving maximum efficiency of communication activities with groups of stakeholder. The process of communication that is marked by qualities of distinctiveness and visibility creates favorable conditions for the formation of organizational differentiation against competitors, whereas transparency characterizes the ability of the organization to develop a confidence of stakeholder groups. Transparency defines the following qualitative measures for the development of relationship: the assumption of responsibility, the efficiency of cooperation and existence of long-term commitments.

With the aim to evaluate the possibilities of representativeness of the empirical research, consumers have been selected from all the groups of stakeholders. As (Mikuleniene \& Jucevicius, 2000) suggest, the equity of consumers, in a broad sense, is one of the essential constituents of relationship equity. The researchers believe that recognition of customers and better perception of their needs distinguish the market leader from the market follower. Whereas (Sontaite, 2011) states that the group of customers influences the organization and their demands are grounded and require immediate actions that explain the need for constant communication of the organization. The assumptions, mentioned above, confirm the relevancy of customers in the context of corporate reputation and relationship management.

The suggested hypothetical model of corporate reputation management (Figure 1) entails consumer-specific factors to perceive corporate reputation. The model also includes the qualities that are typical of the efficient process of integrated communication and corporate reputation management, and the outcomes of reputation management as the cause of specific changes in customer behavior. A broader attitude to customers as the members of the society provides possibilities to extend the set of factors that are applied to perceive corporate reputation and complement it with the factor of social responsibility.

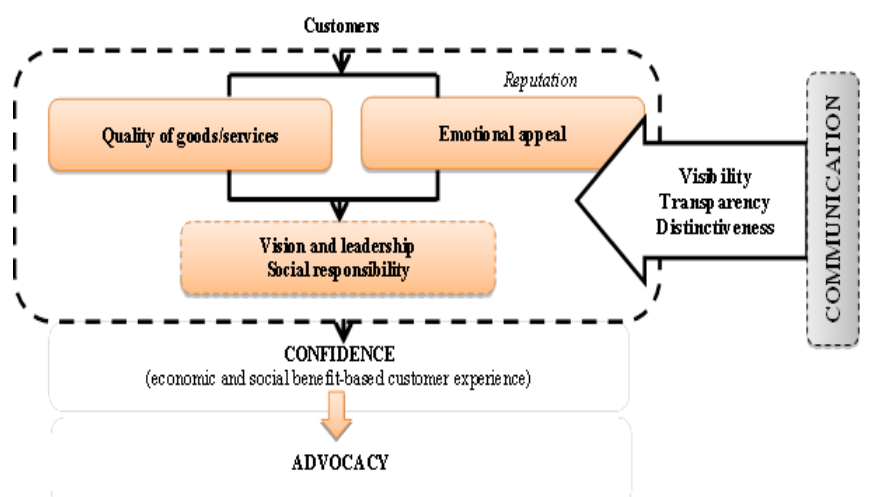

Figure 1. Hypothetical model of corporate reputation management: perspective of customer and corporate communication.

(Source: composed by the authors of the article, with reference to Siano et al., (2007); Helm (2007); Sohn (2010))
Hypothetical model of corporate reputation management, that examines the perception of corporate reputation from a perspective of consumers, is supplemented with a finalized result of the process of corporate reputation management, i.e. changes of customer behavior. The model illustrates the assumption, which indicates that the positive experience of customers, acquired through consumer perceived economic and social value that is formed during the process of relationship development, determines a positive outcome of corporate reputation, i.e. customer advocacy that occurs by means of:

- increasing customer loyalty to the organization; public representation, i.e. a declared confidence of a customer and assumed commitments in respect of the organization;

- increasing need of customer cooperation, i.e. a wish of customers to share information, take part in conflict solving and seek for a mutually favorable possibilities to build relationship with the organization.

When confidence in the organization is examined, advocacy could be treated as the expression of the highest level of commitments that are assumed by consumers. The commitments are based on the highest ratings that customers bestow to the organization. This assumption appeals to the attitude of Johansoozi (2006) and suggests that the acquired confidence in the organization transforms into sustainable and long-term commitments of customers to the organization. Taking this into consideration, the fact that corporate communication and reputation management are an integrated process, the relevancy of the features of the effective corporate communication, i.e. visibility, transparency, distinctiveness, for the perception of corporate reputation by consumers is emphasized in the model.

Visibility. In the context of corporate reputation visibility is regarded as a measure of the publicity and communication frequency of the organization with customers. This dimension of corporate reputation also embeds the direct impact of the identity on corporate reputation, i.e. the ability to develop a desired perception of the organization as a public opinion by means of distinctive visual elements of organizational expression. Visibility in communication usually defines the ability of the organization to ensure constant communication. Then the attributes or features of identity that allow the representatives of stakeholder groups to perceive cultural values of the organization are applied. Transparency. The feature of transparency characterizes the ability of the organization to develop a grounded confidence of various groups of stakeholders. According to (Johansoozi, 2006), transparency defines the following qualitative measures of relationship with customers: assumption of responsibility, efficiency of cooperation and promotion of long-term commitments. Whereas (Berens \& van Riel, 2004; Money \& Hillenbrand, 2006) believe that there are the main five areas of the expression of transparency as the dimension of corporate reputation:

- products and services;

- vision and leadership;

- financial perspective;

- social responsibility;

- working environment. 
Distinctiveness. Van den Bosch et al., (2005) suggest the dimension of transparency to be described as unique position of the organization in relationship to its consumers and other representatives of stakeholder groups. However (Fombrun \& van Riel, 2004) claim that the organization is able to achieve distinctiveness by means of three essential aspects:

- strategic reconciliation that combines the elements of vision and strategy into a solid unit;

- emotionally attractive features that are assigned to the organization;

- manner of communication that is acceptable to stakeholder groups.

The dimension of distinctiveness is usually directed towards specific design decisions, yet, in parallel it could be also attributed to the features of corporate image and communication. Distinctiveness is obtained through a unique creative expression in communication and, therefore, should meet strategic milestones of various elements of visual corporate identity. At the same time it should become an emotionally attractive stimulus to different groups of stakeholders. In summary it could be stated that the dimensions of visibility and distinctiveness, which are assigned to the process of corporate reputation management, reflect the differentiation of corporate communication against the competitors. And transparency is treated as a feature of the process that appeals to the ability of the organization to commit and, on the basis of the commitments, fulfill expectations of customers.

The hypothetical model of corporate reputation management that was developed on the basis of theoretical studies and illustrates the assumption that the positive experience of customers, obtained by means of customer perceived economic and social value, formed in the process of relationship development, determines the essential outcome of positive corporate reputation, i.e. customer advocacy.

Therefore, the empirical research aims at testing or rejecting the assumptions of the hypothetical model of corporate reputation management related with the direct impact of corporate communication on customer perceived corporate reputation and the development of customer confidence on the basis of the perception gained.

\section{Methodology of the empirical research}

The chain restaurants Pizza Jazz were selected for the empirical research since the company:

- has long experience of its performance, is a wellknown company in the society, and the profile of activity as well as the brand-name have not changed since the foundation;

- is distinctive because of the well-developed visual identity and the image that has been structured on the basis of the identity.

The first "Pizza Jazz" restaurant in Lithuania was opened in 1993. Today the "Pizza Jazz" restaurant's network owns eleven restaurants. There are three main sources of competitive advantage for the network of restaurants: the food of the highest quality, friendly service and stylish environment (www.pj.lt).
The empirical research seeks to either prove or reject the assumptions of the hypothetical model of corporate reputation management related with the direct impact of corporate communication on customer perceived corporate reputation and customer confidence, acquired by means of the perception.

The problem of the empirical research aims to find out to what extent the factors of reputation perception of the chain restaurants Pizza Jazz are significant for customers and how communication decisions of the restaurant influence the behavior of customers.

The research focuses on the expression of reputation factors that are relevant for customers of the chain restaurants Pizza Jazz, the communication practice of the restaurant and customer behavior.

The aim of the research is to examine and identify the impact of reputation factors and communication features of the chain restaurants Pizza Jazz on customer behavior.

The tasks of the research are the following:

- to describe customer perceived reputation of the chain restaurants Pizza Jazz, with reference to the evaluation of reputation factors;

- to identify if direct relationship between customer perceived Pizza Jazz reputation, customer confidence and customer advocacy exists;

- to identify if the communication of the chain restaurants Pizza Jazz is directly related to customer perceived restaurant reputation;

- to identify if direct relationship between customer perceived restaurant chain reputation and three features of effective communication, i.e. visibility, transparency and distinctiveness, exists;

- to find out which of the three features of effective communication, i.e. visibility, transparency and distinctiveness, are the most important for customers of the chain restaurants Pizza Jazz.

The aim and tasks of the empirical research lead to the formulation of the following hypotheses:

H1: the reputation of the chain restaurants Pizza Jazz is positively related to customer confidence.

H2: the confidence of the chain restaurants Pizza Jazz customers is positively related to the actions of customer advocacy.

H3: the reputation of the chain restaurants Pizza Jazz is positively related to the actions of customer advocacy.

H4: the communication of the chain restaurants Pizza $J a z z$ is positively related to the reputation of the chain restaurants Pizza Jazz.

H5: visibility as the feature of the communication of the chain restaurants Pizza Jazz is positively related to the reputation of the chain restaurants Pizza Jazz.

H6: transparency as the feature of the communication of the chain restaurants Pizza Jazz is positively related to the reputation of the chain restaurants Pizza Jazz.

H7: distinctiveness as the feature of the communication of the chain restaurants Pizza Jazz is positively related to the reputation of the chain restaurants Pizza Jazz.

With the aim to obtain representative findings of the empirical research it was decided to apply the original research on corporate reputation, which was conducted in the campus of The University of Queensland, Australia in 
2009 and was initiated by researchers (Puncheva-Michelotti \& Michelotti, 2009), as a tool for the empirical research.

The questionnaire for customers was composed of 42 statements that were grouped according to the basic eight factors of corporate reputation, i.e. advantage of corporate management (10 statements), social responsibility (6 statements), results of financial activity of the organization (4 statements); patriotism (4 statements), customer influence (4 statements), emotional appeal of the organization (3 statements), and reliability of the organization (3 statements).

Taking into consideration the specificity of the activity of the chain restaurants Pizza Jazz, the theoretical assumptions of the proposed hypothetical model of corporate reputation management (Figure 1), and the aim and tasks of the empirical research, the suggested tool of the research as devised by (Puncheva-Michelotti \& Michelotti, 2009) was modified and supplemented with new statements. The addition of the new statements was based on the empirical research of corporate reputation that was carried out by (Satir, 2006; Helm, 2007), questionnaires that were used during the research, and individual insights about the distinctiveness of the activity of chain restaurants Pizza Jazz, acquired by the authors of the article. The statements that describe the dimensions of Pizza Jazz reputation, related with the perception, and which are important for customers, were structured on the basis of four factors of corporate reputation, i.e. vision and leadership (10 statements), social responsibility (8 statements), quality of goods and services (7 statements), and emotional appeal (6 statements). Eight additional statements that are related to the evaluation of the results of positive corporate reputation are the following ones: confidence (4 statements), and advocacy (4 statements). The expression ways of efficient communication features were applied to develop nine additional statements that provided possibilities to make decisions about the impact of communication features on the individual customer perception, i.e. visibility (3 statements), transparency (3 statements), and distinctiveness (3 statements).

The statements of the questionnaire were transferred into an e-questionnaire. The selection of the respondents was based on the non-probability method of respondent selection, i.e. non-probability sampling - a convenient or random selection. The data that were collected during the esurvey, were processed by means of the statistical package SPSS and the obtained results were interpreted on the basis of the statistical analysis.

\section{Results of the empirical research}

Respondents. 87 respondents $^{1}$ took part in the empirical research. Women made up more than half of the respondents, i.e. 51 respondents or 58.6 per cent. The majority of the respondents belonged to the age range from 19-25, 63.2 per cent respectively. The average monthly earnings of the majority of the respondents fluctuated on the intervals of 290-435 EUR and 436-480 EUR, 23 per cent and 27.6 per cent respectively.

${ }^{1}$ It was indicated that answers of 78 respondents are substantial to demonstrate that the results of the research represent general opinions with a guarantee of 95 per cent and the survey error of \pm 5 per cent.
The summarized evaluation of the reputation of the chain restaurants Pizza Jazz. Reputation factors that are important for customers of Pizza Jazz restaurants, i.e. the quality of services, social responsibility, vision and leadership and emotional appeal were evaluated on a fivepoint Likert scale. After the corresponding coding of the statistical data and having the aim to obtain a representative numeric value of the reputation of Pizza Jazz restaurants, the variable of reputation that provides possibilities to interpret customer perceived corporate reputation of the chain restaurants and identify the factors that have the biggest influence was derived.

The mean of the reputation variable of the chain restaurants Pizza Jazz equals 3.41 points. With respect to the principle of data coding that was used during the empirical research, the value of the mean on the Likert scale provides the conclusions that the evaluation of Pizza Jazz reputation is more positive rather than negative.

The additional evaluation of reputation factors that are important for customers, expressed through arithmetical means (Table 2), reveals that the emotional appeal of the chain restaurants Pizza Jazz for customers and the quality of services provided are the factors of reputation that condition changes of positive customer perception.

To analyze the research data that represent the factors of customer perceived reputation of Pizza Jazz restaurants and the expression of communication qualities, the KolmogorovSmirnov test was applied. The test demonstrated that four variables did not distribute according the regular distribution (unsatisfying condition $\mathrm{p}>0.05$ ), therefore the nonparameter statistics was further applied and the Spearman correlation coefficient was calculated, (Aaker et al., 2007; Pukenas, 2009; Kasiulevicius \& Denapiene, 2008).

Table 2

Mean values of the evaluation of reputation variable

\begin{tabular}{|c|c|c|c|c|}
\hline $\begin{array}{c}\text { Variable } \\
\text { of } \\
\text { reputation }\end{array}$ & $\begin{array}{c}\text { Quality of } \\
\text { services }\end{array}$ & $\begin{array}{c}\text { Social } \\
\text { responsibility }\end{array}$ & $\begin{array}{c}\text { Vision and } \\
\text { leadership }\end{array}$ & $\begin{array}{c}\text { Emotional } \\
\text { appeal }\end{array}$ \\
\hline $\begin{array}{c}\text { Mean } \\
\text { value of } \\
\text { the } \\
\text { evaluation }\end{array}$ & 3,41 & 3,29 & 3,31 & 3,64 \\
\hline
\end{tabular}

The interpretation of correlation coefficient, related with the need to define the strength of the existing relationship between separate variables of the research, lead to the following conclusions:

- the variables of vision and leadership are positively correlated. Statistically significant and strong link exists between the variables (Spearman's rho $=0.855$ );

- the variables of social responsibility and reputation are positively related. There is a statistically significant and strong link between them (Spearman's rho $=0.746$ );

- the variables of the quality of services and reputation are positively related. There is a statistically significant and strong link between them (Spearman's rho= 0.871);

- the variables of emotional appeal and reputation are positively related. There is a statistically significant and strong link between them (Spearman's rho=0.820); 
- the variables of confidence and reputation are positively related. There is a statistically significant and strong link between them (Spearman's rho=0.732).

The conclusions demonstrate that the findings of the empirical research confirm theoretical assumptions of the hypothetical model of corporate reputation that are related to factors, which are relevant for customers when evaluating the reputation of the organization. The findings indicate that customer perceived vision and leadership of the organization, social responsibility, and quality of services and emotional appeal of the organization are important for the customers, and the total evaluation of the factors reflects customer perceived reputation of the organization.

Validation (rejection) of the hypotheses. The hypotheses that have been presented above are to be either validated or rejected. The process is based on the interpretation of the Spearman correlation coefficients and the results of the regression analysis.

H1: the reputation of the chain restaurants Pizza Jazz is positively related to customer confidence.

The hypothesis $\mathrm{H} 1$ was validated. The value of the Spearman coefficient (0.732) showed that there is a statistically significant and strong link between the reputation of the chain restaurants Pizza Jazz and customer confidence. With the aim to evaluate properly the impact of four reputation factors of the chain restaurants Pizza Jazz that are important for customers, the regressive analysis of the data was conducted. The findings of the analysis lead to the following conclusions:

- the impact of the quality of services, provided by the chain restaurants Pizza Jazz, on customer confidence is statistically significant since the required error of the standard mean Sig. < 0.05 was confirmed;

- the impact of the emotional appeal of the chain restaurants Pizza Jazz on customer confidence in the restaurant is statistically significant, since the required error of the standard mean Sig. $<0.05$ was confirmed;

- the quality of services provided by the chain restaurants Pizza Jazz explains the variation of 45.8 per cent of customer confidence;

- the emotional appeal of the chain restaurants Pizza $J a z z$ on customers explains the variation of 30.4 per cent of customer confidence.

H2: the confidence of the chain restaurants Pizza Jazz customers is positively related to the actions of customer advocacy.

The hypothesis $\mathrm{H} 2$ was approved. The value of the Spearman coefficient $(0.548)$ demonstrated that there is a statistically significant and moderate relation between customer confidence in the chain restaurants Pizza Jazz and the actions of customer advocacy.

H3: the reputation of the chain restaurants Pizza Jazz is positively related to the actions of customer advocacy.

The hypothesis H3 was confirmed. The value of the Spearman coefficient (0.564) demonstrated that there is a statistically significant, but moderate relation between customer perceived reputation of the chain restaurants Pizza $J a z z$ and the advocacy actions of customers. The results of the regression analysis allowed making the following conclusions:
- the impact of the emotional appeal of the chain restaurants Pizza Jazz on advocacy actions of the customers is statistically significant, since the required error of the standard mean Sig. $<0.05$ was confirmed;

- the emotional appeal of the chain restaurants Pizza $J a z z$ on customers explains the variation of 60.4 per cent in advocacy actions of the customers.

H4: the communication of the chain restaurants Pizza Jazz is positively related to the reputation of the chain restaurants Pizza Jazz.

The hypothesis $\mathrm{H} 4$ was confirmed. The value of the Spearman coefficient (0.495) indicated that there is a statistically significant but moderate relation between the communication of the chain restaurants Pizza Jazz and the reputation. Therefore the results of the regression analysis provided the following conclusions:

- the communication of the chain restaurants Pizza $J a z z$ explains 39.1 per cent of the total variation of customer perceived Pizza Jazz reputation;

- the impact of distinctiveness as the feature of communication on customer perceived reputation of the chain restaurants Pizza Jazz is statistically significant since the required error of the standard mean Sig. $<0.05$ was confirmed;

- the distinctiveness of communication of the chain restaurants Pizza Jazz explains 54.4 per cent variation of customer perceived reputation of the chain restaurants.

H5: visibility as the feature of the communication of the chain restaurants Pizza Jazz is positively related to the reputation of the chain restaurants Pizza Jazz.

The hypothesis H5 was confirmed. The value of the Spearman coefficient (0.282) revealed that there is a statistically significant, yet weak link between the visibility of the communication of the chain restaurants Pizza Jazz and customer perceived reputation of the restaurants. The regression analysis demonstrated that the impact of the visibility of communication on customer perceived reputation of the chain restaurants Pizza Jazz is not statistically significant. Thus, the impact of the feature of communication on customer perceived reputation of the chain restaurants will not be further examined.

H6: transparency as the communication feature of the chain restaurants Pizza Jazz is positively related to the reputation of the chain restaurants Pizza Jazz.

The hypothesis H6 was confirmed. The value of the Spearman coefficient (0.312) indicated the fact that there is a statistically significant, yet a weak link between the transparency of communication of the chain restaurants Pizza Jazz and customer perceived reputation of the chain restaurants. The impact of transparency of communication on customer perceived reputation of the chain restaurants Pizza Jazz is statistically insignificant therefore the impact of this dimension of communication on customer perceived reputation of the chain restaurants will not be further examined.

H7: distinctiveness as the communication feature of the chain restaurants Pizza Jazz is positively related to the reputation of the chain restaurants Pizza Jazz.

The hypothesis was confirmed. The value of the Spearman coefficient (0.577) revealed that there is a statistically significant and moderately strong link between 
the distinctiveness of communication of the chain restaurants Pizza Jazz and customer perceived reputation of the chain restaurants. The regression analysis demonstrated that the impact of distinctiveness of communication on customer perceived reputation of the chain restaurants Pizza Jazz is statistically significant. Therefore, the conclusion that the distinctiveness of communication of the chain restaurants Pizza Jazz explains 54.4 per cent variation of customer perceived reputation of the chain restaurants is repeated.

\section{The summary of research findings}

Statistical analysis of the data and corresponding evaluations of statistical coefficients lead to the following generalized conclusions that might be used to provide further recommendations for the chain restaurants Pizza $J a z z$. The generalized conclusions that sum up the empirical research of the reputation of Pizza Jazz restaurants are the following:

- the declared customer perception of the reputation of the chain restaurants Pizza Jazz is positive;

- the vision and leadership of the chain restaurants Pizza Jazz, social responsibility, quality of the services provided, and emotional appeal are empirically grounded factors that are important for the perception of corporate reputation to customers of the chain restaurants;

- the emotional appeal of the chain restaurants Pizza $J a z z$ and the quality of services are the most significant factors of reputation to customers of the chain restaurants; the customer perceived positive reputation of the chain restaurants Pizza Jazz has a positive impact on customer confidence in the restaurants;

- the quality of services that are provided by the chain restaurant Pizza Jazz and the emotional appeal of the restaurants are reputation factors of the chain restaurants that determine confidence of customers in the restaurants;

- the customer confidence in the chain restaurants Pizza Jazz promotes advocacy actions of the customers;

- the emotional appeal of the chain restaurants Pizza $J a z z$ is the factor of the reputation of the chain restaurants that has the biggest impact on advocacy actions of the customers;

- the communication of the chain restaurants Pizza $J a z z$ influences customer perception of the reputation of the chain restaurants;

- the distinctiveness of the communication of the chain restaurants Pizza Jazz exerts the biggest influence on the perception of customers of the reputation of the chain restaurants Pizza Jazz.

The findings of the empirical research provide possibilities to confirm (reject) the theoretical assumptions of the hypothetical model for corporate reputation management (Figure 1). The results suggest a particular foundation for the theoretical validity of the model of corporate reputation management, when the case of the chain restaurants Pizza Jazz is applied. The results of the statistical data analysis, which were obtained during the research of the reputation of the chain restaurants Pizza Jazz, allow adjusting the hypothetical model of corporate reputation management (see Figure 2). The adjustments visually reflect corresponding changes of the theoretical assumptions, which are related to the reputation of the chain restaurants Pizza Jazz.

The adjusted hypothetical model of corporate reputation management visually illustrates changes of three theoretical assumptions:

- emotional appeal to customers is treated as the primary (extremely relevant) factor of corporate reputation;

- social responsibility is treated as the secondary (less relevant) factor of corporate reputation;

- distinctiveness is treated as the main feature of corporate communication that determines the efficiency of communication.

The summary of the changes of the theoretical assumptions expounds that during the case analysis of the chain restaurants Pizza Jazz the relevance of corporate reputation factors has changed, yet this does not reject the complex validity of all the reputation factors that are examined by means of the hypothetical model of corporate reputation management. Taking into consideration the information, that was obtained during the empirical research, about the factors that shape the reputation of the chain restaurants Pizza Jazz, with reference to its customers as well as the impact of the perceived reputation and the communication of the restaurant on customer confidence and actions of advocacy, it is possible to state that in communication practices of the chain restaurants all reputation factors (quality of services, emotional appeal, vision and leadership, and social responsibility) that shape the perception of customers, need to be reinforced.

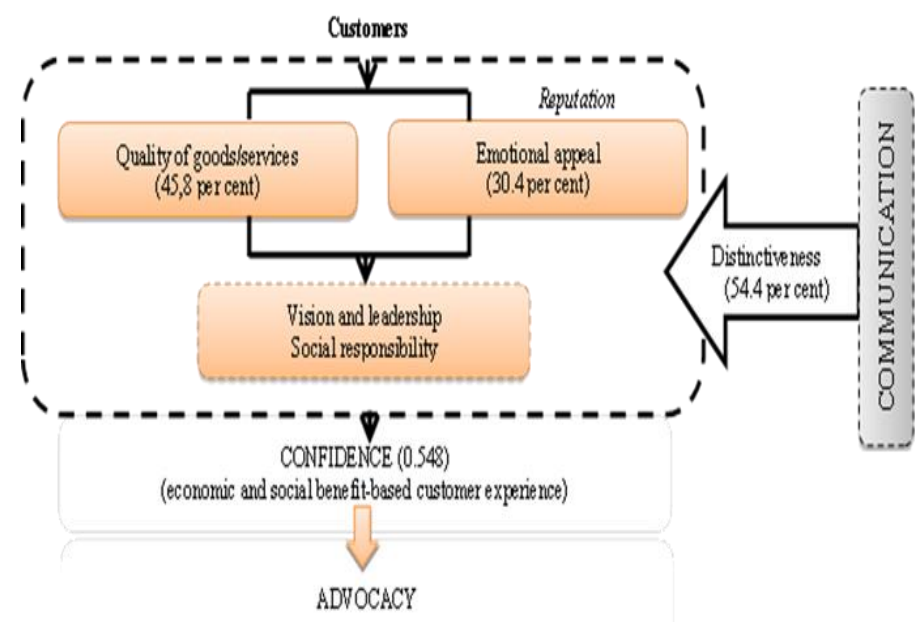

Figure 2. Adjusted hypothetical model of corporate reputation management: perspective of communication between customers and the organization (the example of the chain restaurants Pizza $J a z z)$

\section{Conclusions}

1. In up-to-date scientific literature corporate reputation management is more frequently associated with the integrated development of communication and relationship. Strong corporate reputation is treated as a variable that determines favorable behavior of stakeholder groups. The results of the behavior are associated with positive changes of results of organizational performance.

2. General corporate reputation is a construct that embeds the collective perception of the organization, or, in 
other words, it is a synthesis of opinions, expectations and attitudes of differently characterized groups of stakeholders. Therefore, separate evaluations of corporate reputation converge in-between and structure one generalized perception of corporate reputation. Meanwhile the ability of the organization to structure this type of experience could be considered as a full-fledged competitive advantage.

3. The most relevant variable in corporate reputation management is direct experience of customers related to the usage of goods and services. The direct experience of customers appeals not only to the quality of goods/services but also emphasizes the generalized evaluation of organizational performance against other groups of stakeholders. The building of relationship with consumers and the parallel corporate reputation management have become the underlying activities of the organization.

4. Corporate communication and reputation management are an integrated process that reveals the significance of features (visibility, transparency, and distinctiveness) of efficient corporate communication in the light of customer perceived corporate reputation.

5. The hypothetical model of corporate reputation management that was developed on the basis of theoretical studies, illustrates a theoretical assumption and states that positive experience of customers, which was acquired by means of the economic and social value, formed during the process of relationship building, determines the essential outcome of positive corporate reputation, i.e. customer advocacy that occurs by means of increasing loyalty of customers towards the organization, public representation (a declared confidence of customers and assumed commitments to the organization), and the increasing need of cooperation (the wish of customers to share information participate in conflict solutions and seek for mutually favorable possibilities to build relationship with the organization).

6. The results of the empirical research provided the possibilities to adjust the hypothetical model of corporate reputation management by means of three changes of theoretical assumptions:
- emotional appeal to customers is treated as the primary (extremely relevant) factor of corporate reputation;

- social responsibility is treated as the secondary (less relevant) factor of corporate reputation;

- distinctiveness is treated as the basic feature of corporate communication that determines the efficiency of communication.

7. During the research of corporate reputation of Pizza $J a z z$ chain restaurants the relevancy of the factors of corporate reputation changed, yet this does not deny the complex validity of all the factors that are examined by means of the hypothetical model of corporate reputation management.

8. Taking into consideration the information about the factors that shape customer perception of the corporate reputation of Pizza Jazz chain restaurants, that was obtained during the empirical research, the impact of the perceived reputation and the communication of the chain restaurants on customer confidence and advocacy actions, it is recommended:

- to strengthen all reputation factors (quality of services, emotional appeal, vision and leadership, and social responsibility) that shape the perception of customers in all practices of the chain restaurants;

- to consider the reinforcement of emotional appeal to customers and the development of quality-based expectations as priority areas of corporate communication;

- to enhance social responsibility in the context of human resource management;

- to seek for the efficiency of communication through the increased level of the publicity of communication, strengthened visual identity, and to apply in practice the qualities of efficient content of the communication that is addressed to customers (simplicity, laconicism, and relevancy).

\section{References}

Aaker, D. A., Kumar, V., \& Day, G. S. ( 2007). Marketing Research. 9th Edition Hoboken, New Jersey: Wiley.

Berens, G., \& van Riel, C. B. M. (2004). Corporate Associations in the Academic Literature: Three Main Streams of Thought in the Reputation Measurement Literature. Corporate Reputation Review, 7(2), 161-178. http://dx.doi.org/10.1057/ palgrave.crr.1540218

van den Bosch, A. L. M., de Jong, M. D. T., \& Elving, W. J. L. (2005). How Corporate Visual Identity Supports Reputation. Corporate Communications: An International Journal, 10(2), 108-116 http://dx.doi.org/10.1108/13563280510596925

Chun, R. (2005). Corporate Reputation: Meaning and Measurment. International Journal of Management Reviews, 7(2), 91109. http://dx.doi.org/10.1111/j.1468-2370.2005.00109.x

Covey, S. M. R., Stephen, R. Covey, S. R., \& Merrill, R. R. (2008). The SPEED of Trust: The One Thing That Changes Everything. Published by Simon\&Shuster New York.

Dickinson-Delaporte, S., Beverland, M., \& Lindgreen, A. (2010). Biulding Corporate Reputation with Stakeholders: Exploring the Role of Message Ambiguity for Social Marketers. European Journal of Marketing, 44(11/12), 1856-1874. http://dx.doi.org/10.1108/03090561011079918

Doorley, J., \& Garcia, H. (2011). Reputation Management: The key to successful public relations and corporate communication ( $2^{\text {nd }}$ edition). Abingdon: Routledge.

Gotsi, M., \& Wilson, A. M. (2001). Corporate Reputation: Seeking a Definition. Corporate Communications: an International Journal, 6(1), 24-30. http://dx.doi.org/10.1108/13563280110381189 
Greyser, S. A. (2009). Corporate Brand Reputation and Brand Crisis Management. Management Decision, 47(4), 590-602. http://dx.doi.org/10.1108/00251740910959431

Helm, S. (2007). One Reputation or Many? Comparing Stakeholders' Perceptions of Corporate Reputation. Corporate Communications: an International Journal, 12(3), 238-254. http://dx.doi.org/10.1108/13563280710776842

Highhouse, S., Brooks, M. E., \& Gregarus, G. (2009). An Organizational Impression Management Perspective on the Formation of Corporate Reputations. Journal of Management, 35, 1481- 1493. http://dx.doi.org/10.1177/ 0149206309348788

Johansoozi J. (2006). Organization-Stakeholders Relationships: Exploring Trust and Transparency. Journal of Management Development, 25 (10), 942-955. http://dx.doi.org/10.1108/02621710610708577

Kasiulevicius, V., Denapiene, V. (2008). Statistikos taikymas moksliniu tyrimu analizeje. Teorija ir praktika. Gerontologija, 9(13), 176-180.

Mikuleniene, R., Jucevicius, R. (2000). Organizacijos intelektinis kapitalas: sandaros ir pagrindiniu sąvoku interpretacijos/ Socialiniai mokslai. 3(24), 65-76.

Money, K., \& Hillenbrand, C. (2006). Using Reputation Measurement to Create Value: an Analysis and Integration of Existing Measures. Journal of General Management, 32(1), 1-12.

Neville, B. A., Bell, S. J., \& Menguc, B. (2005). Corporate Reputation, Stakeholders and the Social Performance-Financial Performance Relationship. European Journal of Marketing, 39(9/10), 1184-1198. http://dx.doi.org/10.1108/ 03090560510610798

Pukenas, K. (2009). Kokybiniu duomenu analize SPSS programa. Mokomoji knyga. Lietuvos kuno kulturos akademija. Kaunas: LKKA, 93.

Puncheva, P. (2008). The Role of Corporate Reputation in the Stakeholder Decision-Making Process. Business \& Society, 47(3), 272. http://dx.doi.org/10.1177/0007650306297946

Puncheva-Michelotti, P., \& Michelotti, M. (2010). The Role of the Stakeholders Perspective in Measuring Corporate Reputation. Marketing Intelligence \& Planning, 28(3), 249-274. http://dx.doi.org/10.1108/02634501011041417

Romenti, S. (2010). Reputation and Stakeholder Engagement: an Italian Case Study. Journal of Communication Management, 14(4), 306-318. http://dx.doi.org/10.1108/13632541011090428

Satir, C. (2006). The Nature of Corporate Reputation and the Measurement of Reputation Components: An Emprical Study Within a Hospital. Corporate Communications: An International Journal, 11(1), 56 - 63 http://dx.doi.org/10.1108/ 13563280610643552

Shamma, H. M., \& Hassan, S. S. (2009). Customer and Non-Customer Perspectives for Examing Corporate Reputation. Journal of Product \& Brand Management, 18(5), 326-337. http://dx.doi.org/10.1108/10610420910981800

Siano, A., Vollero, A., \& Siglioccolo, M. (2007). Corporate Reputation Management: a Set of Drivers in the GovernanceStructure-System Model. Empirical Evidences from Crisis Communication, Competitive Paper, 11th International Conference on Reputation, Brand, Identity \& Competitiveness. Available from internet: http://dsc.unisa.it/Siano/siano _dw/Reputation\%20Management\%20Oslo.pdf

Sohn, Y. (2010). Toward Building the Relationships-Reputation Integrated Model. International Journal of Integrated Marketing Communications, 2(2), 19-34.

Sontaite, M. (2011). Suinteresuotu grupiu vaidmuo korporatyvines reputacijos valdyme. Organizaciju vadyba: sisteminiai tyrimai, Nr. 60, 129-138.

Walker, K. (2010). Systematic Review of the Corporate Reputation Literature: Definition, Measurement and Theory. Corporate Reputation Review, 12(4), 357-387. http://dx.doi.org/10.1057/crr.2009.26

Karolina Petrokaite, Jurgita Stravinskienè

Organizacijos reputacijos valdymas: vartotojų perspektyva

Santrauka

Didejjantis organizaciju veiklos skaidrumo poreikis, komunikacijos poveikio svarba bei dinamiška verslo aplinka skatina kalbeti apie naują požiūri komunikaciją ir santykius su organizacijai aktualiomis suinteresuotuju grupèmis - reputacijos valdymą, kurio rezultatyvumas dažnai apibūdinamas reputacijos teikiama finansine ir strategine nauda. Minèta prielaida leidžia teigti, jog suinteresuotuju grupių lūkesčiai ir patirtis yra strategiškai svarbūs reputacijos valdymo sprendimų antecedentai.

Santykiu kapitalo ir komunikacijos perspektyvos aspektu analizuojama organizacijos reputacija, dažniausiai nukreipta į vartotojų - kaip svarbiausios suinteresuotuju grupès - lūkesčius ir patirti. Tačiau praktikoje, vis dar nèra lengvai adaptuojamų tokio pobūdžio organizacijos reputacijos valdymo metodiku. iprasminančių reputacijos valdymo sprendimų poveikị tvariam vartotojų pasitikèjimui organizacija. Todèl mokslinè problema formuluojama klausimu: kokią itaką organizacijos reputacija daro vartotojų pasitikejjimui organizacija?

Tyrimo objektas - organizacijos reputacijos valdymas.

Straipsnio tikslas - parengti hipotetini organizacijos reputacijos valdymo modeli ir ji empiriškai patikrinti vartotojų požiūriu.

Tyrimo metodai: mokslinės literatūros sisteminè ir palyginamoji analizè, koreliacinè ir regresinè duomenu analizè, elektroninès apklausos metodas.

Apibendrinta Weigelt ir Camerer (1988), Fombrun (1996), Weiss (1999), Bennett ir Kottasz (2000), Fombrun ir van Riel (2004) pozicija organizacijos reputacijos atžvilgiu, leidžia teigti, jog organizacijos reputacija yra rinkinys atributų, atspindinčių organizacijos praeities elgsenos rezultatus, gebëjimą 
patenkinti lūkesčius bei ju pagrindu kurti vertę, suinteresuotuju grupių atžvilgiu (Chun, 2005). Dera pabrěžti, jog socialinëje plotmëje organizacijos reputacija priskiriama kolektyvinių susitarimu kategorijai, kitaip tariant, tai yra viešoji nuomoné apie organizacija, pagrista organizacijos elgsenos modeliu.

Remiantis Puncheva (2008) teigimu, organizacijos reputacija yra vienas aktualiausių veiksnių, lemiančiu suinteresuotujų grupių sprendimu prièmimo proceso rezultatus. Tai yra pakankamai svari prielaida, leidžianti teigti, jog organizacijos prisiimami isipareigojimai ir atitinkamai besiformuojantys suinteresuotuju grupių lūkesčiai, yra esminiai organizacijos reputacijos tobulinimo motyvai, patvirtinantys organizacijos reputacijos aktualumą sprendimų prièmimo ir santykių plètojimosi procesuose. Romenti (2010) teigimu, būtent suinteresuotuju grupių lūkesčiai yra pagrindinis organizacijos reputacijos valdymo elementas.

Siano, Vollero ir Siglioccolo (2007) teigimu, pats aktualiausias kintamasis organizacijos reputacijos valdymo metu yra tiesioginè vartotoju patirtis organizacijos prekiu/paslaugu atveju. Dera akcentuoti, jog tiesioginè vartotoju patirtis apeliuoja ne tik i prekiu/paslaugu kokybę, bet ir i apibendrintą organizacijos veiklos îvertinimą kitų suinteresuotuju grupių akivaizdoje (Helm, 2007). Etiškas ir socialiai atsakingas organizacijos elgesys, igyvendinamas per koncentruotas ir kiekybiškai išmatuojamas iniciatyvas (investicijos i ekologiškos produkcijos gamybos linijas ir tinkamas žaliavas, vartotoju švietimas vadovaujantis verslo etikos principais ir pan.), formuoja viešają nuomonę apie organizacijos elgseną, kuri atitinkamai veikia organizacijos i̇vaizdžio ir reputacijos pokyčius. Šiuo atveju, santykiu su vartotojais plètra ir lygiagretus organizacijos reputacijos valdymas tampa prioritetinėmis organizacijos veiklomis.

Apibendrinus mokslines diskusijas, padaryta išvada, kad bendroji organizacijos reputacija - tai kolektyvini suvokimą apie organizaciją iprasminantis konstruktas, arba kitaip tariant - savo charakteristikomis skirtingų suinteresuotuju grupių nuomonių, lūkesčiu ir požiūriu sintezė. Atskiri organizacijos reputacijos vertinimai konverguoja tarpusavyje, suformuodami vieną apibendrintą organizacijos reputacijos suvokimą, o organizacijos gebẻjimas formuoti šią patirtị gali būti laikomas pilnaverčiu konkurenciniu pranašumu.

Remiantis Siano, Vollero, Siglioccolo (2007); Greyser (2009); Romenti (2010); Doorley, Garcia (2011) požiūriais, jog organizacijos reputacijos ir komunikacijos valdymas yra vienas integruotas procesas, hipotetinio organizacijos reputacijos valdymo modelio sudarymo prielaidos įvardytos šios:

- Pagrindiniai organizacijos reputacijos suvokimo veiksniai yra emocinis patrauklumas, prekiu ir paslaugų kokybė, vizija ir lyderystė, finansinès veiklos rezultatai, darbo aplinkos sąlygos ir socialinè atsakomybè ( Helm, 2007).

- Endogeniniai organizacijos reputacijos veiksniai, apibūdinantys aktyvią organizacijos komunikacinę elgseną, yra viešieji ryšiai, santykiai su žiniasklaida, i̇vairių formų reklama, viešai prieinama informacija apie organizaciją komunikacija visuomenei aktualiomis temomis (Siano, Vollero, Siglioccolo, 2007).

- Geidžiama ir palanki organizacijos reputacija yra igyvendinama per visas organizacijos identiteto raiškos sritis - organizacijos elgseną, komunikacija ir simbolizmą. Organizacijos reputacijos ir identiteto sąveika atsiskleidžia per penkias esmines organizacijos reputacijos dimensijas: matomumą, savituma, autentiškumą, skaidrumą ir nuoseklumą (Bosch, Jong ir Elving, 2005).

- Organizacijos reputacija priklauso nuo suinteresuotuju grupių susiformavusio pasitikèjimo ir pagarbos organizacijos atžvilgiu (Siano, Vollero ir Siglioccolo, 2007; Berens ir Riel, 2004).

Vertinant empirinio tyrimo reprezentatyvumo galimybes, iš visų suinteresuotujų grupių pasirinkti vartotojai, nes plačiaja prasme vartotojų kapitalas yra viena esminių santykių kapitalo dedamujų (Mikulènienè ir Jucevičius, 2000). Siūlomas hipotetinis organizacijos reputacijos valdymo modelis apibendrina vartotojams būdingus organizacijos reputacijos suvokimo veiksnius, efektyviam integruotos komunikacijos ir reputacijos valdymo procesui būdingas savybes bei su konkrečiais vartotojų elgsenos pokyčiais siejamas organizacijos reputacijos valdymo pasekmes. Platesnis požiūris i i vartotojus, kaip i visuomenès narius, leidžia išplèsti organizacijos reputacijos suvokimo veiksniu rinkini, papildant ji socialinès atsakomybès veiksniu. Hipotetinis organizacijos reputacijos valdymo modelis, kuriame analizuojama organizacijos reputacijos suvokimo perspektyva, vartotoju atveju papildytas baigtiniu organizacijos reputacijos valdymo proceso rezultatu - vartotojų elgsenos pokyčiais. Modelis iliustruoja prielaidą jog pozityvi vartotojų patirtis, igyta per vartotojų suvoktą ekonominę ir socialinę santykių metu suformuotą vertę, lemia esminę teigiamos organizacijos reputacijos pasekmę - vartotojų advokatavimą, pasireiškiantį per: didèjanti vartotojų lojalumq organizacijos atžvilgiu; viešą atstovavima, t.y. vartotojo deklaruojamą pasitikèjimą ir prisiimamus issipareigojimus organizacijos atžvilgiu; didejjantị vartotojų bendradarbiavimo poreikį - vartotojų norą dalintis informacija, dalyvauti sprendžiant konfliktus ir siekti abipusiai palankiu galimybiu santykiuose su organizacija.

Empirinio tyrimo rezultatai, pasirinkus „Pizza Jazz“ restoranų tinklo pavyzdi, leido pakoreguoti hipotetini organizacijos reputacijos valdymo modeli teorinių prielaidų pokyčiais:

- emocinis patrauklumas vartotojams yra traktuojamas kaip pirminis (labai aktualus) organizacijos reputacijos veiksnys;

- socialinè atsakomybè yra traktuojama kaip antrinis (mažiau aktualus) organizacijos reputacijos veiksnys;

- savitumas yra traktuojamas kaip pagrindinè, komunikacijos efektyvumą lemianti organizacijos komunikacijos savybè.

Apibendrinus šiuos teoriniu prielaidų pokyčius, pastebėtas organizacijos reputacijos veiksnių aktualumo „Pizza Jazz“ restoranų tinklo atveju kitimas. Tačiau tai nepaneigia kompleksinio visu, hipotetiniame organizacijos reputacijos valdymo modelyje analizuojamu reputacijos veiksniu pagristumo. Atsižvelgiant ị empirinio tyrimo metu gautą informaciją apie „Pizza Jazz“ restoranų tinklo reputaciją vartotojų atžvilgiu formuojančius veiksnius, suvokiamos reputacijos bei restoranų tinklo komunikacijos įtaką vartotojų pasitikëjimui ir advokatavimo veiksmams, padaryta išvada, jog restoranų tinklo komunikacijos praktikoje turi būti stiprinami visi, vartotojų suvokimą formuojantys reputacijos veiksniai: paslaugų kokybė, emocinis patrauklumas, vizija ir lyderyste bei socialinè atsakomybè.

Raktažodžiai: organizacijos reputacija, organizacijos reputacijos valdymas, suinteresuotosios grupess, vartotojuperspektyva, komunikacija.

The article has been reviewed.

Received in March, 2013; accepted in December, 2013. 